Article

\title{
Exogenous Application of Proline and L-Cysteine Alleviates Internal Browning and Maintains Eating Quality of Cold Stored Flat 'Maleki' Peach Fruits
}

\author{
Gholamreza Gohari ${ }^{1, *(\mathbb{D})}$, Sanaz Molaei ${ }^{2}\left(\mathbb{D}\right.$, Azizollah Kheiry ${ }^{2}$, Mahshid Ghafouri ${ }^{2}$, \\ Farhang Razavi $^{2}\left(\mathbb{D}\right.$, Jose M. Lorenzo ${ }^{3,4, *(\mathbb{D})}$ and Antonio Juárez-Maldonado ${ }^{5, *(D)}$
}

check for

updates

Citation: Gohari, G.; Molaei, S.; Kheiry, A.; Ghafouri, M.; Razavi, F.; Lorenzo, J.M.; Juárez-Maldonado, A. Exogenous Application of Proline and L-Cysteine Alleviates Internal Browning and Maintains Eating Quality of Cold Stored Flat 'Maleki' Peach Fruits. Horticulturae 2021, 7, 469. https://doi.org/10.3390/ horticulturae7110469

Academic Editor: Juan A. Salazar

Received: 27 September 2021 Accepted: 3 November 2021 Published: 5 November 2021

Publisher's Note: MDPI stays neutral with regard to jurisdictional claims in published maps and institutional affiliations.

Copyright: (c) 2021 by the authors. Licensee MDPI, Basel, Switzerland. This article is an open access article distributed under the terms and conditions of the Creative Commons Attribution (CC BY) license (https:/ / creativecommons.org/licenses/by/ $4.0 /)$.
1 Department of Horticulture, Faculty of Agriculture, University of Maragheh, Maragheh 83111-55181, Iran

2 Department of Horticulture, Faculty of Agriculture, University of Zanjan, Zanjan 45371-38791, Iran; smolaie@znu.ac.ir (S.M.); kheiry@znu.ac.ir (A.K.); mahshidghafouri2000@yahoo.com (M.G.); razavi.farhang@znu.ac.ir (F.R.)

3 Centro Tecnológico de la Carne de Galicia, Avd. Galicia n 4, Parque Tecnológico de Galicia, San Cibrao das Viñas, 32900 Ourense, Spain

4 Área de Tecnología de los Alimentos, Facultad de Ciencias de Ourense, Universidad de Vigo, 32004 Ourense, Spain

5 Departamento de Botánica, Universidad Autónoma Agraria Antonio Narro, Saltillo 25315, Coahuila, Mexico

* Correspondence: gohari.gh@maragheh.ac.ir (G.G.); jmlorenzo@ceteca.net (J.M.L.); antonio.juarez@uaaan.edu.mx (A.J.-M.)

\begin{abstract}
The postharvest life of flat peach fruit is limited by the appearance of chilling injury symptoms, especially internal browning. In this study, impacts of the exogenous application of proline $(0,5,10$, and $15 \mathrm{mM})$ and L-cysteine $(0,0.2,0.4$ and $0.6 \%)$ on attenuating chilling injury of flat peach fruit were evaluated all over the cold storage. The results demonstrated that the fruits treated with $15 \mathrm{mM}$ proline and $0.4 \%$ L-cysteine showed lower levels of internal browning and these treatments prevented the excess enhancement of total soluble solids (TSS), the decline of titratable acidity (TA) content and the loss of fruit firmness during storage time. A lower accumulation of hydrogen peroxide $\left(\mathrm{H}_{2} \mathrm{O}_{2}\right)$, malondialdehyde (MDA), electrolyte leakage, and higher activity of antioxidant enzymes, along with higher ascorbic acid content and antioxidant capacity, were observed in treated fruits. Treated fruits also showed higher activity of phenylalanine ammonia lyase (PAL) and conversely lower activity of polyphenol oxidase (PPO), which led to a higher accumulation of total phenols and flavonoids. Moreover, a higher accumulation of endogenous proline was observed in $15 \mathrm{mM}$ proline treated fruits. Eventually, according to our results, the exogenous administration of proline and L-cysteine as safe, natural and environmentally friendly treatments, preserved the nutritional quality of flat peach fruits during long-term cold storage.
\end{abstract}

Keywords: antioxidant capacity; membrane integrity; polyphenol oxidase; postharvest life; Prunus persica

\section{Introduction}

The flat peach (Prunus persica (L.) Batsch 'Maleki') as a mutation of the standard peach, has high economic value due to excellent texture and taste and also being a unique source of phenolic compounds such as flavonoids, anthocyanin, and so forth [1,2]. Peach as a climacteric fruit is vulnerable to rapid senescence and decay at ambient temperature. The changes of texture occur as a result of pectin degradation enzymes such as polygalacturonase (PG) and pectin methylesterase. The oxidation of phenolic compounds mainly by polyphenol oxidase (PPO) leads to flesh and skin browning [3,4]. Nevertheless, storing the fruit in cold storage (close to $0^{\circ} \mathrm{C}$ ) is suggested to alleviate undesirable changes and extend storage life. However, the high sensitivity of stone fruit to low temperatures and the appearance of some symptoms such as skin and flesh browning, declining flavor, mealy 
texture, failure to ripen and softening as a result of the inhibition of ethylene production, limits the employment of cold storage [2,5]. Therefore, cold storage combined with various postharvest treatments is used to extend storage life and reduce chilling injury symptoms, for example, carbon monoxide [6], hot air and water [7], citric acid [8] and jasmonic acid [2].

L-cysteine as a precursor of endogenous $\mathrm{H}_{2} \mathrm{~S}$ is generally recognized as safe. This compound is one of the most efficient agents of anti-browning which is widely applied alone or in combination with various coatings and organic acid in harvested horticultural crops [9-11]. Under cold temperature and oxidative stress, L-cysteine prevents the activity of PPO and peroxidase (POD) enzymes and snare o-quinones by expanding colorless compounds. These products are recognized as cysteinyl-adducts which are responsible for inhibiting the PPO activity $[10,12,13]$. The anti-browning impact of L-cysteine has been reported in various studies on different crops, such as pear [14], apple [15], eggplant [16], litchi [10], longan [11] and broccoli [17].

Proline as a proteinogenic amino acid naturally rises under abiotic stress by the enhancement of proline synthesis or the reduction of proline degradation [18]. Proline plays a main role in preserving the osmotic balance, stabilizing the structure of enzymes and membranes in key proteins, protecting the photosynthetic products and scavenging free radicals [19]. Proline in higher plant synthesis by glutamate and ornithine pathways show that the glutamate pathway is dominant. In this pathway, pyrroline-5-carboxylate (P5CS) and pyrroline-5-carboxylate reductase (P5CR) are responsible for the biosynthesis of proline from L-glutamic [20]. Numerous studies have been conducted about the impacts of exogenous proline on various crops under oxidative stress, namely, the exogenous application of proline in rose, rice seedlings, chickpeas and citrus enhanced the stress tolerance by increasing the activity of antioxidant enzymes, declining membrane lipid peroxidation and retaining the ascorbic acid content as non-enzymatic parts of the antioxidant system [21-24].

According to the available evidence about the positive effects of proline and L-cysteine on the postharvest life of various crops, seems these two compounds may be effective for postponing the senescence process and alleviating the adverse effects of oxidative stress. So, the objective of the present study as the first study on the impact of proline and L-cysteine on the storage life of flat peaches is to evaluate the effect of different concentrations of exogenous proline and L-cysteine on the browning index (BI) and visual and nutritional quality of flat peaches throughout the cold storage at $2{ }^{\circ} \mathrm{C}$ for 28 days.

\section{Materials and Methods}

\subsection{Peach Fruit and Treatment}

Flat peach (Prunus persica (L.) Batsch 'Maleki') fruits were harvested at commercial maturity from six years' old trees of a commercial orchard located in West Azerbaijan province, Iran. The fruit of this variety has an intermediate size, a very flat shape, a fine texture, white flesh, a small stone size and late harvest maturity. All in all, 'Maleki' is a variety with intermediate productivity and excellent eating quality [25]. Harvested fruits were immediately transported to the laboratory and uniform fruits without any disease, mechanical damage and pests were selected. For application of treatments, 720 fruits (total fruit number) in three replications and 60 fruits per treatment, immersed in L-cysteine $(0 \%, 0.2 \%, 0.4 \%$ and $0.6 \%)$ and proline $(0,5,10$, and $15 \mathrm{mM})$ solutions for $15 \mathrm{~min}$ at $25^{\circ} \mathrm{C}$. Then, treated fruits were air-dried at ambient temperature for $2 \mathrm{~h}$. Afterward, fruits were transported to cold storage with $80-90 \%$ relative humidity $(\mathrm{RH})$ and $2 \pm 0.5^{\circ} \mathrm{C}$ temperature for 28 days. Every 7 days, 15 fruits from every treatment were selected to evaluate the browning index, firmness and biochemical criteria.

\subsection{Browning Index}

The level of flesh browning was estimated visually by cutting the fruits parallel to the axial diameter and assessment of the level of visible browning on the flesh surface. The flesh BI was computing based on a five-point grade which was described by Wang 
et al. [26]. The rating scale was: $0=$ no signs of flesh browning, $1=1-25 \%$ flesh surface was brown, $2=26-50 \%$ flesh surface was brown, $3=51-75 \%$ flesh surface was brown and $4=>76 \%$ flesh surface was brown. The BI was calculated with the formula below:

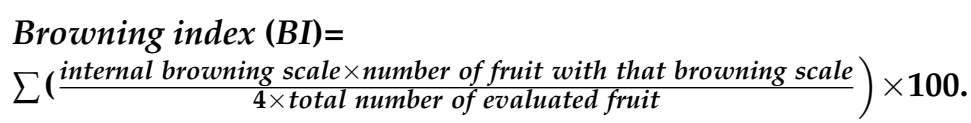

\subsection{Firmness, TSS and TA}

To measure fruit firmness, the skin of some areas of fruit was removed and then a penetrometer with an $8 \mathrm{~mm}$ diameter flat probe was used. Fruit firmness was expressed by $\mathrm{N}$ force [2]. To determine the total soluble solids (TSS) and titratable acidity (TA), fruits were juiced and filtered. Then, a hand refractometer was used for determining TSS content; and for measuring TA content, $10 \mathrm{~mL}$ of fruit juice was titrated by $0.1 \mathrm{~N} \mathrm{NaOH}$ until it reached $\mathrm{pH} 8.2$ [27].

\subsection{Electrolyte Leakage, $\mathrm{MDA}$ and $\mathrm{H}_{2} \mathrm{O}_{2}$ Accumulation}

Electrolyte leakage was measured by the method described by Chen et al. [28]. To determine the initial electrolyte leakage, six discs $(10 \mathrm{~mm})$ of pericarp tissue were in $0.3 \mathrm{M}$ mannitol solution for $30 \mathrm{~min}$ and were assayed by conductivity meter. Then, discs were heated at $98^{\circ} \mathrm{C}$ and cooled to measure final electrolyte leakage and were expressed as a percentage. The thiobarbituric acid (TBA) method [29] was used to assay malondialdehyde (MDA) accumulation. One gram of fruit tissue was mixed with $5 \%(v / v)$ trichloroacetic acid (TCA) and centrifuged at $10,000 \times g$ for $10 \mathrm{~min}$. Then, supernatant $(1.5 \mathrm{~mL})$ was mixed with $0.5 \%$ TBA $(2.5 \mathrm{~mL})$ and $15 \%$ TCA, and was held in boiling water for $30 \mathrm{~min}$. After centrifuging the mentioned mixture, the absorbance was recorded at $532 \mathrm{~nm}$ and the accumulation of MDA was represented based on nmol g ${ }^{-1} \mathrm{FW}$. To assay, the content of the $\mathrm{H}_{2} \mathrm{O}_{2}$ the method expressed by Patterson et al. [30] was employed and the content of $\mathrm{H}_{2} \mathrm{O}_{2}$ was represented as nmol g ${ }^{-1} \mathrm{FW}$ of fresh weight.

\subsection{DPPH Scavenging Activity, Ascorbic Acid Content, and the Activity of Antioxidant Enzymes}

The DPPH (2,2-diphenyl-1-picrylhydrazyl) scavenging activity was determined by the method presented via Dehghan and Khoshkam [31]. The DPPH solution (1.9 mL) was added to $0.1 \mathrm{~mL}$ of the fruit sample and left in a dark place for $30 \mathrm{~min}$. Finally, the absorbance was measured at $517 \mathrm{~nm}$ and the DPPH scavenging activity was expressed in the form of (\%). To estimate the content of ascorbic acid, 2,6-dichlorophenolindophenol (DCIP) dye was used [32]. In this method, the flesh tissue ( $2 \mathrm{~g})$ was homogenized with methaphosphoric acid $(1 \% v / v)$. After centrifuging, the supernatant was separated and added to the indicator solution (2.6-dichlorophenolindophenol solution and sodium bicarbonate). Eventually, $520 \mathrm{~nm}$ was used to measure the absorbance. The ascorbic acid content was represented as $\mathrm{mg} 100 \mathrm{~g}^{-1} \mathrm{FW}$. The activities of antioxidant enzymes, including superoxide dismutase (SOD), catalase (CAT) and ascorbate peroxidase (APX), were assayed according to the method described by Zhang et al. [33]. To prepare the enzyme extract, $5 \mathrm{~g}$ of frozen flesh tissue was homogenized in $50 \mathrm{mM}$ of phosphate buffer (pH 7.8) that contained polyvinylpolypyrrolidone (PVPP) $(2 \%)$ and ethylene di amine tetra acetic acid (EDTA) $(0.2 \mathrm{Mm})$. After centrifuging at $12,000 \times \mathrm{g}$ for $20 \mathrm{~min}$ at $4{ }^{\circ} \mathrm{C}$, the homogenate mixture was used as the enzyme extract. The activity of one unit of SOD is explained as the enzyme causing a 50\% inhibition of NBT decline under experimental conditions. The activity of one unit of CAT was expressed as a reduction in absorbance at $240 \mathrm{~nm}$ of 0.01 per min and the amount of enzyme that could oxidize $1 \mu \mathrm{M}$ of ascorbate per minute is described as one unit of APX activity. The activities of the mentioned enzymes were represented in units generated per mass of protein ( $\mathrm{U} \mathrm{mg}^{-1}$ protein). 


\subsection{Total Phenol, Flavonoids and Proline Content}

The content of total phenols was determined using the Folin-Ciocalteu method [34] $0.1 \mathrm{~mL}$ of $50 \%(v / v)$ and $0.1 \mathrm{~mL}$ of extract (methanol/water 70:30 $v / v$ was used to prepare extract) was added to the Folin-Ciocalteu reagent and allowed to react for $2 \mathrm{~min}$ at room temperature. After adding the $\mathrm{Na}_{2} \mathrm{CO}_{3}(2 \%)$ solution, the mixture was put away for $30 \mathrm{~min}$ and, then, the absorbance was recorded t $720 \mathrm{~nm}$. Finally, the content of total phenols was expressed based on mg gallic acid equivalents (GAE) per $\mathrm{kg}$ fresh weight ( $\left.\mathrm{mg} \mathrm{GAE} \mathrm{kg}{ }^{-1} \mathrm{FW}\right)$. The method of aluminum chloride colorimetric that was reported by Zhishen et al. [35] was used to evaluate the accumulation of flavonoids. In this method, $0.25 \mathrm{~mL}$ of sample was added to aqueous $\mathrm{NaNO}_{2}(5 \%)$. Then, $\mathrm{AlCl}_{3}(10 \%)$ was added to the solution. Next, $1 \mathrm{~mol} / \mathrm{L} \mathrm{NaOH}$, and distilled water was added to reach $2.5 \mathrm{~mL}$ as a final volume and the absorbance was recorded at $510 \mathrm{~nm}$. The total content of flavonoids was expressed based on mg quercetin equivalents (QE) of per $\mathrm{kg}$ fresh weight (mg QE kg-1 FW). Proline content was measured following the method described by Sanchez et al. [36] with a little modification and the usage of ninhydrin reagent. To prepare the extract, flesh tissue $(2 \mathrm{~g})$ was ground and shaken in hot sulfosalicylic acid for $10 \mathrm{~min}$. The extract was centrifuged at $12,000 \times g$ for $20 \mathrm{~min}$ at $4{ }^{\circ} \mathrm{C}$. The supernatant was mixed with a 1:1 solution of glacial acetic acid and ninhydrin reagent and was boiled for $30 \mathrm{~min}$. Then, toluene was added to the solution, and the absorbance was recorded at $520 \mathrm{~nm}$. Finally, the calculation of data was performed based on the standard curve. The accumulation of proline was expressed as $\mu \mathrm{g} \mathrm{g}^{-1}$ fresh weight (FW).

\subsection{PAL and PPO Activity}

The PAL and PPO activities were measured based on Nguyen et al. [37] by minor changes and $1 \mathrm{~g}$ of frozen flesh tissue was homogenized in $50 \mathrm{mM}$ borate buffer $(\mathrm{pH}$ 8.5) (2-mercaptoethanol, EDTA, PVPP). Then, the mixture was centrifuged at $15,000 \times g$ for $20 \mathrm{~min}$ at $4{ }^{\circ} \mathrm{C}$ and the supernatant used as an enzyme extract. One unit of PAL activity was defined as $1 \mu \mathrm{mol}$ of cinnamic acid generated per minute. To prepare the PPO extract, $0.1 \mathrm{M}$ citric buffer at $\mathrm{pH} 6.2$ was used to homogenize $1 \mathrm{~g}$ of frozen fruit tissue. The activity of one unit of $\mathrm{PPO}$ was explained as a change of 0.01 of absorbance at $410 \mathrm{~nm}$ per minute. The activities of these enzymes were represented in units generated per mass of protein ( $\mathrm{U} \mathrm{mg}^{-1}$ protein).

\subsection{Statistical Analysis}

This experiment was performed in a factorial layout of a completely randomized design. All treatments contain three replicates and 60 fruits were in each replicate. The data were analyzed using analysis of variance (ANOVA) by SAS version 9.2 (SAS Institute Inc. Cary, NC, USA, 2003). The differences between mean values were compared by the least significant difference (LSD) test at the $5 \%$ significant level $(p<0.05)$.

\section{Results}

\subsection{Browning Index}

Internal browning, as one of the main symptoms of chilling injury, was observed in both treated and control fruits after 14 days and increased until the end of storage. On the other side, the application of exogenous proline and L-cysteine could delay the increase of internal browning, so, the lowest level (19.03\% and 22.43\%) of BI belonged to $15 \mathrm{mM}$ proline and $0.4 \%$ L-cysteine respectively, after 28 days of storage (Figure 1a,b). So, according to the superior performance of these two treatments ( $15 \mathrm{mM}$ proline and L-cysteine $0.4 \%)$ in reducing $I B$, they were chosen for statistical comparison with the untreated control with regard to all the remaining parameters. 


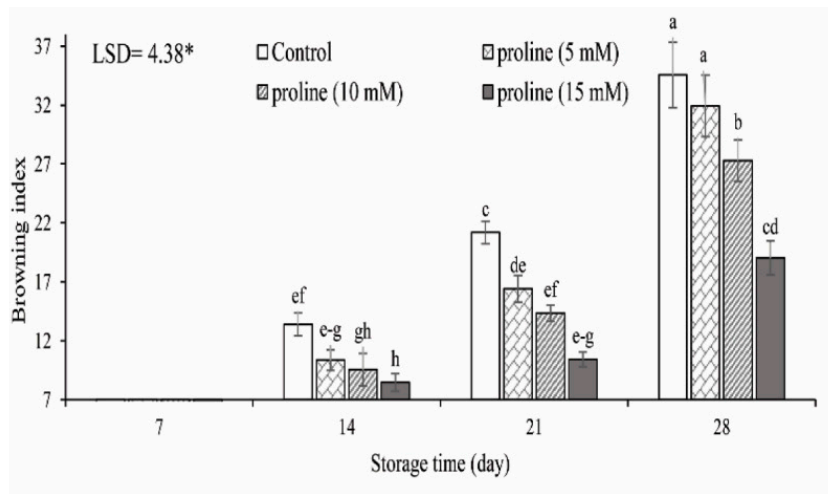

(a)

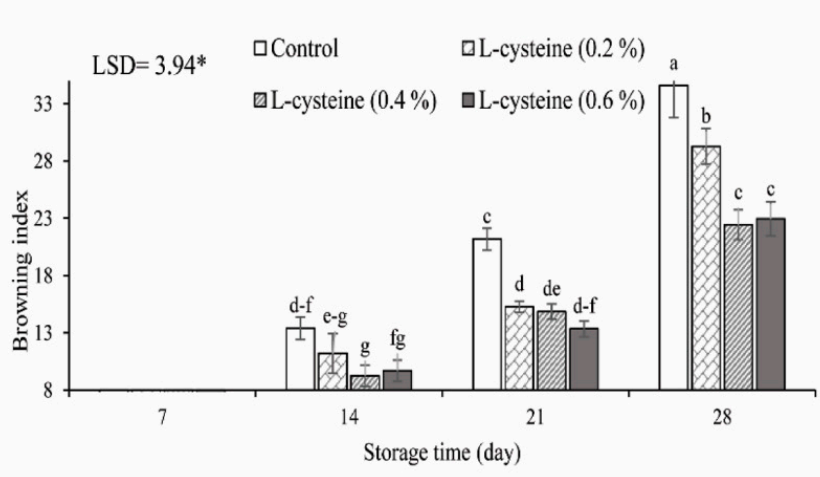

(b)

Figure 1. Browning index alteration in flat peach in response to postharvest administration of proline (a) and L-cysteine (b) during storage at $2{ }^{\circ} \mathrm{C}$ for 28 days. ${ }^{*}$ Shows significance level at $p \leq 0.05$. Values are the mean $\pm \mathrm{SE}$.

\subsection{TSS, TA Content and Fruit Firmness}

TSS content showed an increasing trend across the storage time; however, this increasing trend was less intense in treated fruits. At the end of the storage period, the highest (14.1\%) amount of TSS content was detected in control fruits and the lowest $(12.03 \%)$ amount was found in fruits treated by L-cysteine $0.4 \%$ (Figure $2 a$ ). TA content declined during the 28 days of storage time but in treated fruits TA content was retained at a higher level in comparison to the control. So, at the end of the storage time, higher $(0.36 \%)$ and lower $(0.25 \%)$ amounts of TA content were observed in the L-cysteine $0.4 \%$ treated and control fruits, respectively (Figure 2b). The firmness of all fruits declined throughout the cold storage time, but in treated fruits, the level of this criterion was preserved at a higher level. At the end of the storage period, a higher $(13.9 \%)$ level of fruit firmness was observed in $0.4 \%$ L-cysteine treated fruits and the lower (7.98\%) level belonged to the control fruits (Figure 2c).

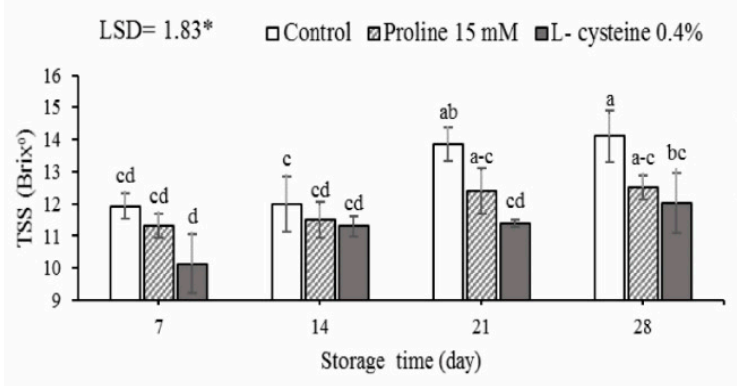

(a)

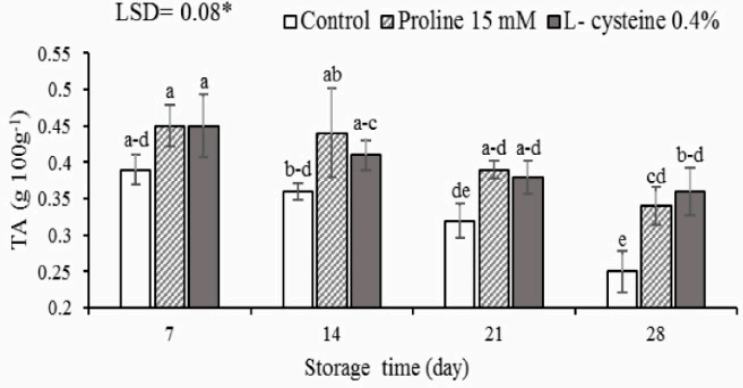

(b)

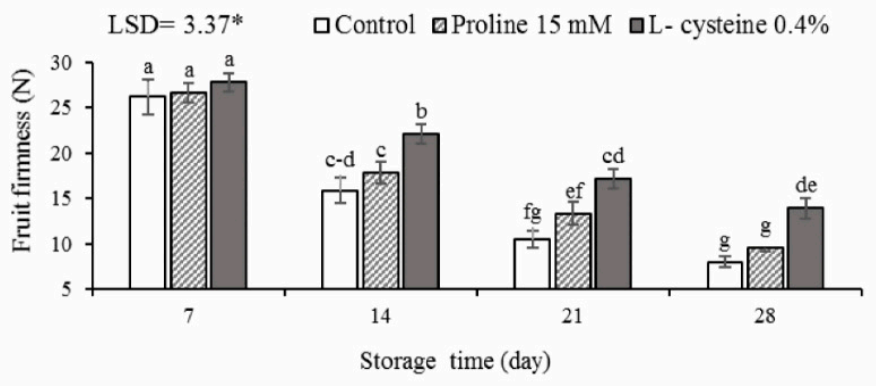

(c)

Figure 2. TSS (a), TA (b) content and fruit firmness (c) alteration in flat peach in response to postharvest administration of $15 \mathrm{mM}$ proline and $0.4 \% \mathrm{~L}$-cysteine during storage at $2{ }^{\circ} \mathrm{C}$ for 28 days. ${ }^{*}$ shows a significant level at $p \leq 0.05$. Values are the mean \pm SE. 


\subsection{DPPH Scavenging Activity, Ascorbic Acid Content, and the Activity of Antioxidant Enzymes}

The DPPH scavenging activity in both treated and control fruits was enhanced from 7 to 21 days of storage period and afterwards, in the control and $0.4 \%$ L-cysteine treated fruits, a decreasing trend was observed but in $15 \mathrm{mM}$ proline treated fruits, an increasing trend continued up to the end of the storage time (Figure 3a). At the end of the storage time, no significant difference was observed between the antioxidant capacity of fruits treated with $15 \mathrm{mM}$ proline and $0.4 \% \mathrm{~L}$-cysteine. The content of ascorbic acid decreased in all fruits (control and treated) throughout the storage time. However, in the control fruit, the declining trend was more intense than in the treated fruits (Figure $3 b$ ). The activity of SOD raised in all fruits up to 21 days of storage time and then decreased slightly during last week of the storage period and the highest (139.03 $\mathrm{U} \mathrm{mg}^{-1}$ protein) level of SOD activity was observed in fruits treated with $15 \mathrm{mM}$ proline after the passing of storage time (Figure 3c). The CAT activity of all fruits increased during 28 days of storage time, but in treated fruits, especially $15 \mathrm{mM}$ proline treated fruits, the enhancement of this enzyme activity was significantly higher than that of the control fruits (Figure 3d). The APX activity of all treated fruits was enhanced throughout the storage time; however, the activity of this enzyme increased in control fruits during 21 days of storage and then declined slightly until the end of the storage time (Figure $3 \mathrm{e}$ ).

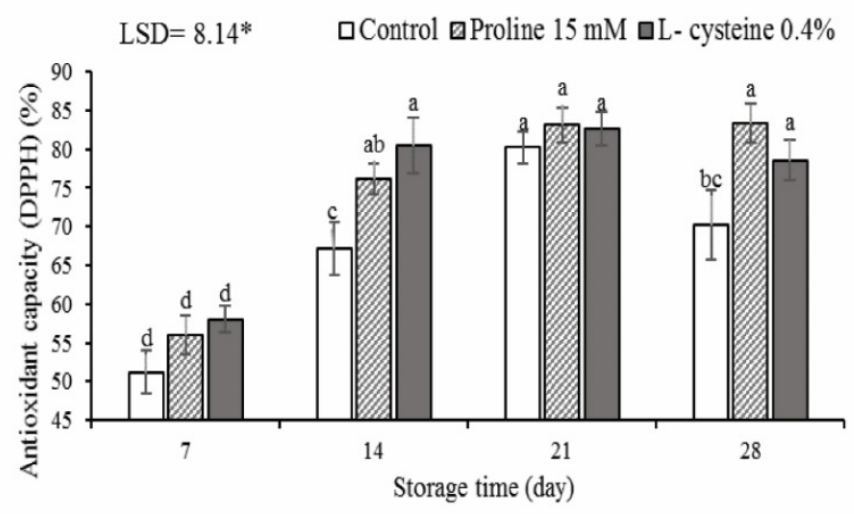

(a)

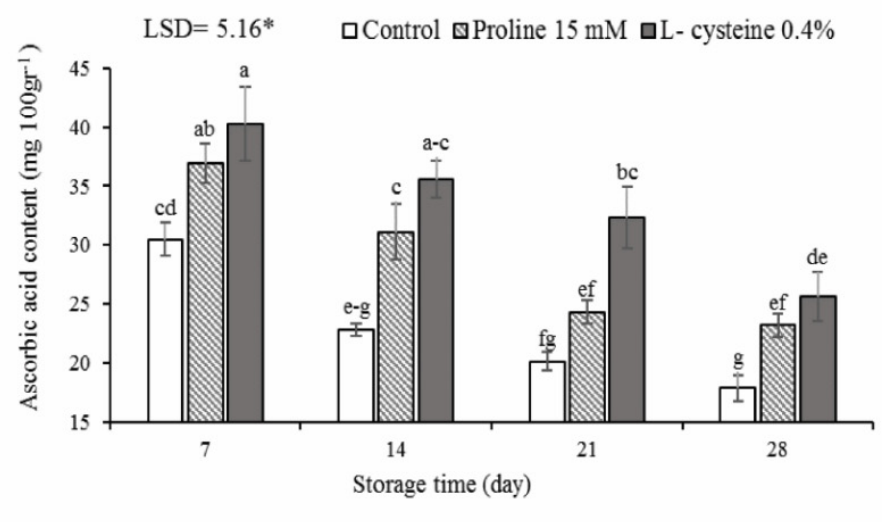

(b)

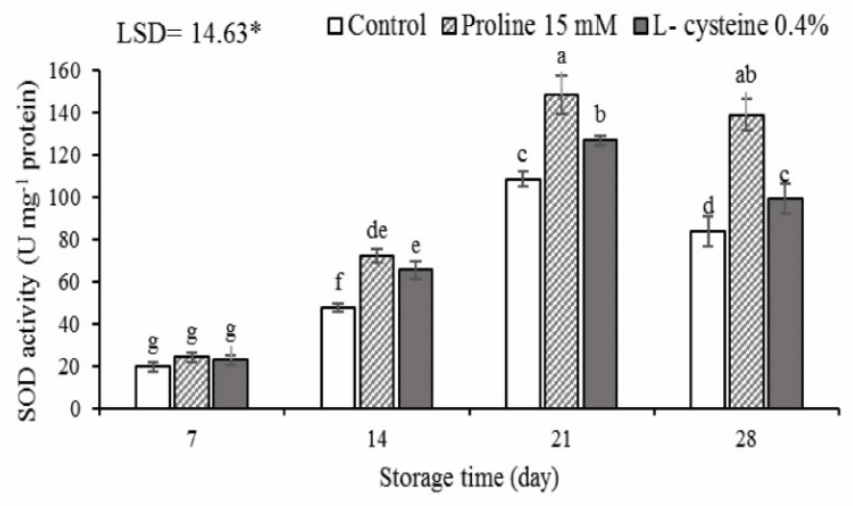

(c)

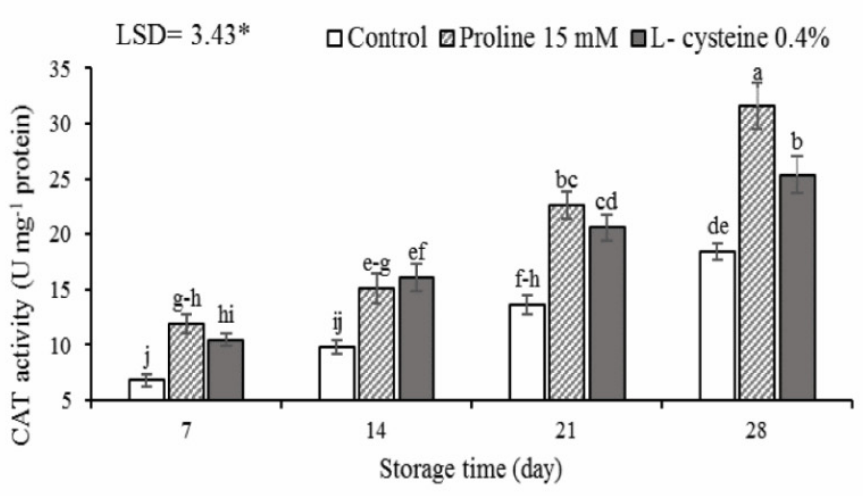

(d)

Figure 3. Cont. 


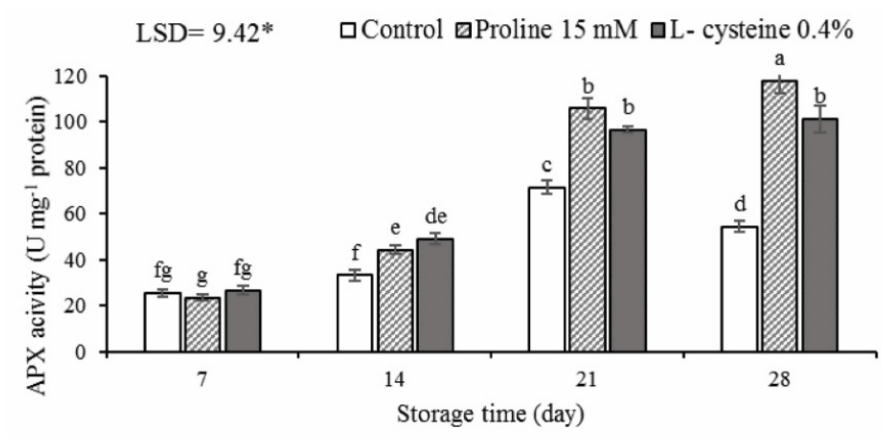

(e)

Figure 3. Antioxidant capacity (DPPH) (a), ascorbic acid content (b), SOD (c), CAT (d) and APX (e) activity alteration in flat peach in response to postharvest administration of $15 \mathrm{mM}$ proline and $0.4 \%$ L-cysteine during storage at $2{ }^{\circ} \mathrm{C}$ for 28 days. * Shows a significant level at $p \leq 0.05$. Values are the mean $\pm \mathrm{SE}$.

\subsection{Electrolyte Leakage, $\mathrm{MDA}$ and $\mathrm{H}_{2} \mathrm{O}_{2}$ Accumulation}

Electrolyte leakage and MDA accumulation rose in all fruits throughout the storage period. However, in treated fruits, the content of these criteria retailed at a lower level in comparison to control fruits and at the end of the storage period, $15 \mathrm{mM}$ proline treated fruits represented the lowest content of MDA and EL (Figure 4a,b). However, there were no significant differences between $15 \mathrm{mM}$ proline and $0.4 \%$ L-cysteine at the level of electrolyte leakage at the end of the storage time. The content of $\mathrm{H}_{2} \mathrm{O}_{2}$ rose in all fruits by passing the storage time, but in treated flat peach fruits the increase of $\mathrm{H}_{2} \mathrm{O}_{2}$ content was controlled and showed a lower level than the control fruits (Figure 4c).

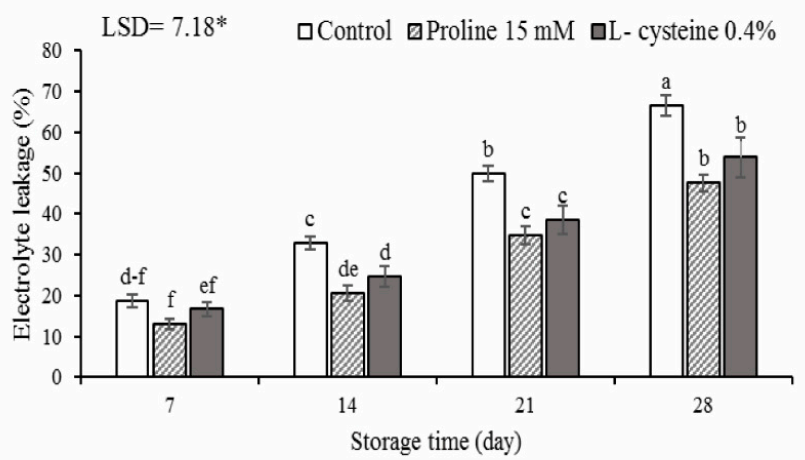

(a)

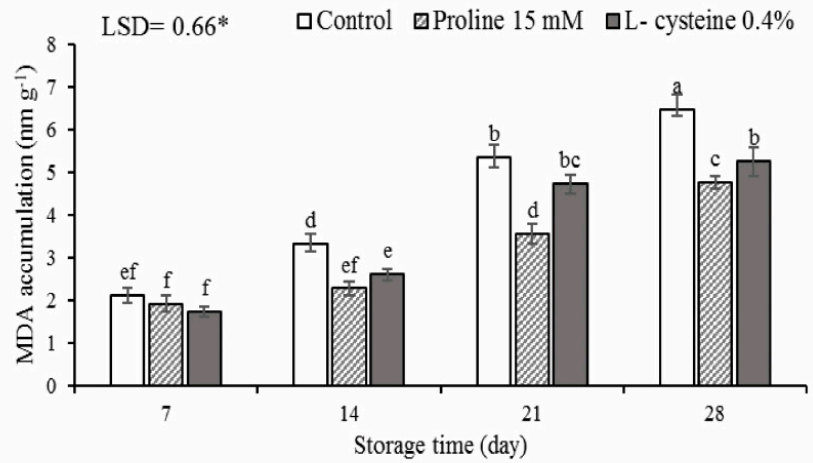

(b)

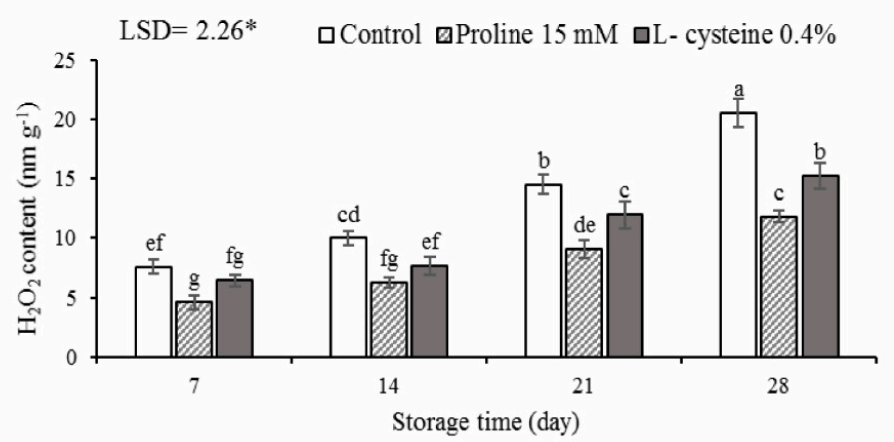

(c)

Figure 4. Electrolyte leakage (a), MDA (b) and $\mathrm{H}_{2} \mathrm{O}_{2}$ (c) accumulation alteration in flat peach in response to postharvest administration of $15 \mathrm{mM}$ proline and $0.4 \% \mathrm{~L}$-cysteine during storage at $2{ }^{\circ} \mathrm{C}$ for 28 days. ${ }^{*}$ Shows a significant level at $p \leq$ 0.05 . Values are the mean $\pm \mathrm{SE}$. 


\subsection{Total Phenol, Flavonoids and Endogenous Proline Content}

The total phenol content of all fruits were enhanced during the first three weeks and then decreased over the last week of storage time. After 28 days of cold storage, the highest (122.37 mg GAE $100 \mathrm{~g}^{-1} \mathrm{FW}$ ) value of total phenolic content was observed in $0.4 \%$ L-cysteine treated fruits (Figure 5a). The content of flavonoids showed an increasing trend throughout the storage time but in $15 \mathrm{mM}$ proline treated fruits; this trend was more severe and reached $26.9 \mathrm{mg} \mathrm{QE} 100 \mathrm{~g} \mathrm{~g}^{-1} \mathrm{FW}$ at the end of the storage period (Figure $5 \mathrm{~b}$ ). Based on the obtained results, the proline content of all fruits enhanced all over the storage time, but in exogenous proline treated fruits this increasing trend was significantly more severe than in other fruits (Figure $5 c$ ).

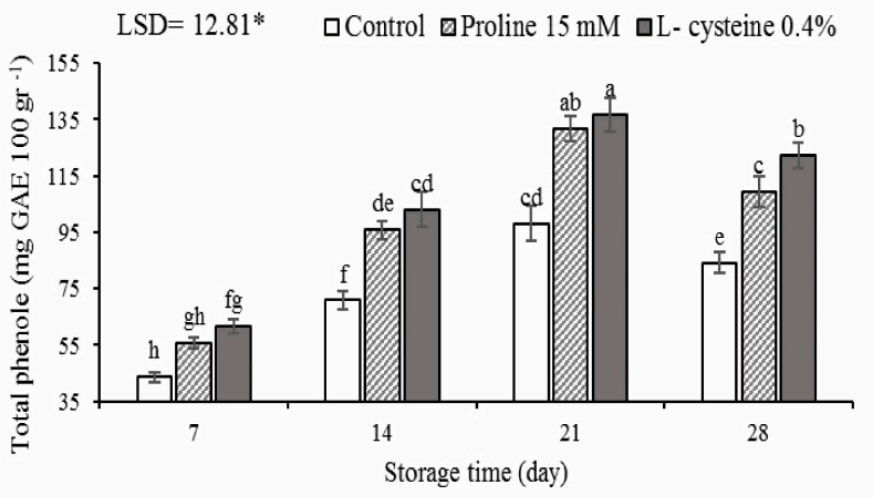

(a)

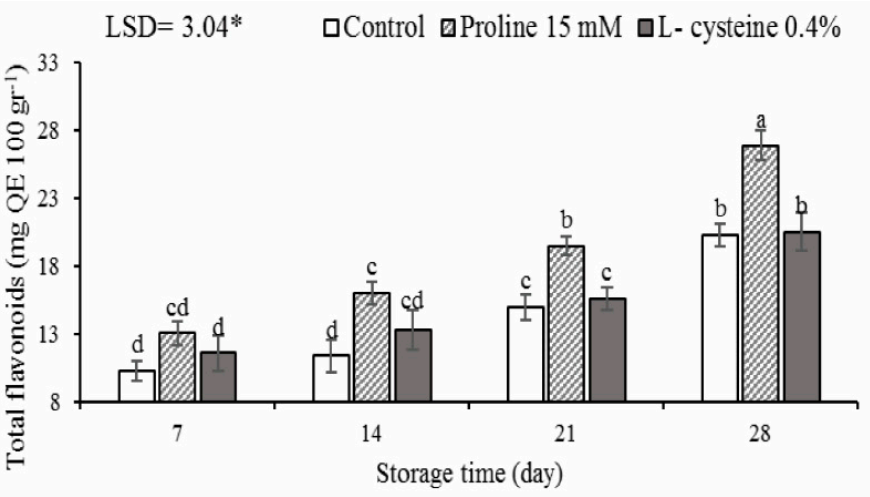

(b)

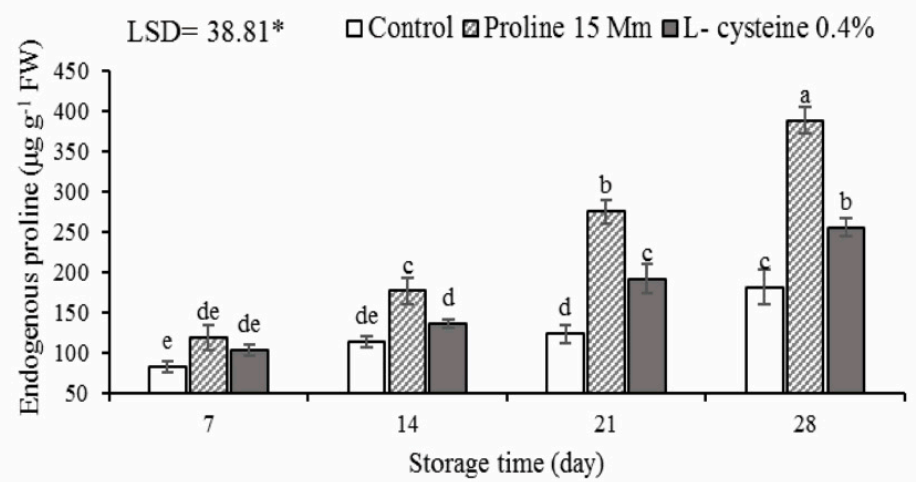

(c)

Figure 5. Total phenol (a), flavonoids (b) and endogenous proline (c) content alteration in flat peach in response to postharvest administration of $15 \mathrm{mM}$ proline and $0.4 \% \mathrm{~L}$-cysteine during storage at $2{ }^{\circ} \mathrm{C}$ for 28 days. ${ }^{*}$ Shows a significant level at $p \leq 0.05$. Values are the mean $\pm \mathrm{SE}$.

\subsection{PAL and PPO Activity}

The PAL activity of treated fruits rose as the storage period progressed, but in the control fruits, the PAL activity increased during 21 days of storage and then declined slightly. At the end of the storage time, the highest and the lowest amount of PAL activity were perceived in $15 \mathrm{mM}$ treated and control fruits, respectively (Figure 6a). The results showed that PPO activity was enhanced in both treated and control fruits but the application of treatments could prevent more increasing of this enzyme activity during the cold storage. So, at the end of storage, the highest level of PPO activity belonged to the control fruits (Figure 6b). 


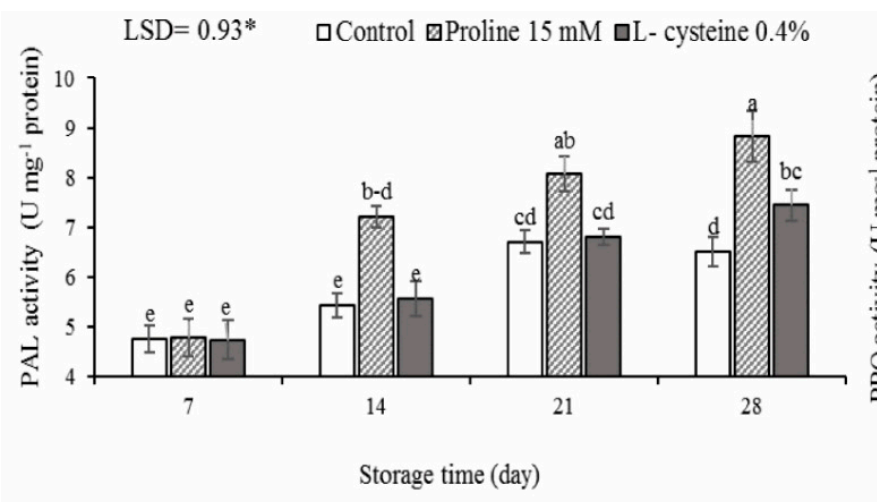

(a)

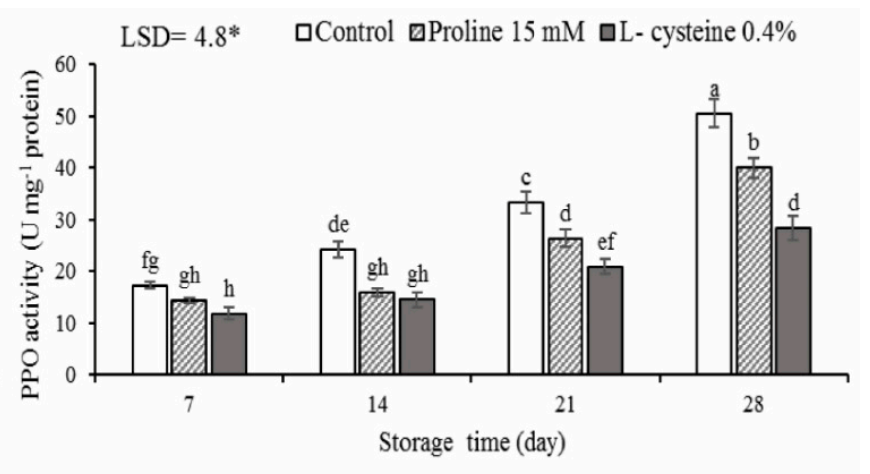

(b)

Figure 6. The activity of PAL (a) and PPO (b) alteration in flat peach in response to postharvest administration of $15 \mathrm{mM}$ proline and $0.4 \% \mathrm{~L}$-cysteine during storage at $2{ }^{\circ} \mathrm{C}$ for 28 days. ${ }^{*}$ Shows a significant level at $p \leq 0.05$. Values are the mean \pm SE.

\section{Discussion}

Internal browning is one of the main disorders of peach fruits during storage life, which appears after long-term storage at low temperatures [5,6]. Determining the BI is a practical method to evaluate internal browning, which is attributed to the oxidation of phenolic compounds by PPO and POD [38]. These enzymes oxidize phenolic compounds to quinone and quinine-like compounds that produce polymerized brown pigments $[6,39]$. In the current study, the results showed that $15 \mathrm{mM}$ proline and $0.4 \%$ L-cysteine treated peach fruits exhibited lower internal browning in comparison to control fruits during cold storage. Various studies have presented some evidence of the efficiency of proline and L-cysteine in reducing internal browning. For example, in litchi [10], longan [40], artichokes [41], lettuce [9], Pholiota nameko mushroom [42] and in plums [43], the application of different concentrations of L-cysteine reduced internal browning. In the case of proline, the application of this compound inhibited the tissue browning by reducing the activity of PPO activity in rice [44] and spinach leaves [45].

TSS and TA are the main criteria that significantly relate to the taste as well as the effects on the nutritional value of fruits $[46,47]$. In harvested fruits, the senescence process is associated with declined flavor and nutritional quality. So, maintaining TSS and TA content in a suitable level and preventing TA decomposition in L-cysteine and proline-treated fruits, may be relevant to suppress the starch alteration to simple sugars [10]. Similar results were reported in carambola [48], litchi [10] and longan [11], which were treated with L-cysteine, and in peach fruits treated with glycine betaine [49].

The loss of fruit firmness is one of the factors that reduces the quality of harvested fruits by the polymerization and destruction of cell wall compounds. The activity of pectinmethylestrase (PME) and polygalacturonase (PG) leads to the degradation of the cell wall. Pectin converts to low methylpectin or pectin acid by PME and PG is responsible for reducing the molecular weight of polymers and decreasing the fruit firmness by hydrolyzing the glycosidic linkages of the pectin substance [50]. In this study, retaining higher fruit firmness in $15 \mathrm{mM}$ proline and $0.4 \%$ L-cysteine treated fruits may be related to the reduction of PME and PG activity. In fresh-cut mango, apple, pear and melon application of anti-browning agents, such as L-cysteine, decreased the loss of fruit firmness during the storage period [51,52].

The low temperature storage increases the production of reactive oxygen species (ROS) molecules, which thereby reduced cell membrane integrity by altering the structure of the cell membrane from pliable liquid crystal-line to solid-gel. Exposing the plant to long-term cold stress caused lacerations of the cell membrane and caused leakage of intracellular water, ions and metabolites [38]. Under oxidative stress in various plants, ROS molecules, such as superoxide $\left(\mathrm{O}_{2}{ }^{-}\right)$, hydroxyl $\left(\mathrm{OH}^{-}\right)$, hydrogen peroxide $\left(\mathrm{H}_{2} \mathrm{O}_{2}\right)$ radicals, singlet oxygen and lipid hydroperoxides, are produced by the incomplete reduction of oxygen [53]. 
These molecules are highly unstable and reactive which makes them able to damage cells by the removal of electrons or the peroxidation of cell membrane lipids [54]. The peroxidation of cell membrane lipids enhances the saturation degree of fatty acids, the degradation of phospholipids and galactolipids and the ratio of sterol/phospholipids, which eventually reduces the efficiency and fluidity of cell membrane. MDA as the secondary end-product of lipid peroxidation is used to evaluate the peroxidation of membrane fatty acids [10,38]. Electrolyte leakage is a useful parameter for the determination of cell membrane permeability and shows the level of membrane integrity [55]. In the current study, a lower level of electrolyte leakage, MDA and $\mathrm{H}_{2} \mathrm{O}_{2}$ were observed in fruits treated with $15 \mathrm{mM}$ proline and $0.4 \%$ L-cysteine during cold storage. These phenomena demonstrated that proline and L-cysteine reduced membrane permeability and prevented the peroxidation of membrane fatty acids. Low electrolyte leakage, MDA and $\mathrm{H}_{2} \mathrm{O}_{2}$ accumulation as a result of L-cysteine application were reported in tuberose cut flowers [56], tobacco [57], litchi [10] and plums [43]. In addition, the application of exogenous proline in rice [22], citrus [24] and barley [58] exhibited reduced MDA and $\mathrm{H}_{2} \mathrm{O}_{2}$ accumulation and electrolyte leakage.

The activity of the ROS scavenging enzymatic system helps to scavenge ROS and increase the defense system against oxidative stress. This system contains two steps: in step one, SOD generates $\mathrm{H}_{2} \mathrm{O}_{2}$ from $\mathrm{O}_{2}{ }^{-}$and in the second step, CAT produces $\mathrm{O}_{2}$ from $\mathrm{H}_{2} \mathrm{O}_{2}$ as well as $\mathrm{H}_{2} \mathrm{O}$ is generated from $\mathrm{H}_{2} \mathrm{O}_{2}$ by APX. Furthermore, ascorbic acid is a non-enzymatic part of the ROS scavenging system, donor electron to APX for scavenging $\mathrm{H}_{2} \mathrm{O}_{2}$ by the ascorbate-glutathione cycle. APX eliminates $\mathrm{H}_{2} \mathrm{O}_{2}$ by consuming ascorbic acid and producing dehydroascorbate (DHA). Glutathione reductase (GR) generates ascorbic acid from DHA by consuming glutathione $[59,60]$. So, a higher amount of ascorbic acid in $15 \mathrm{mM}$ proline and $0.4 \%$ L-cysteine treated peach fruit may be related to APX/GR activity. According to the result of the current study, higher activity of SOD, CAT and APX is concurrent with a higher accumulation of ascorbic acid and declining $\mathrm{H}_{2} \mathrm{O}_{2}$ content in treated fruits. This phenomenon may have prevented the occurrence of chilling injury symptoms, especially internal browning, by preventing peroxidation of membrane lipids and loss of cell membrane integrity. Several studies have reported the beneficial effect of L-cysteine in increasing non-enzymatic and enzymatic antioxidants as found in carambola [48], litchi [10], longan [11] and plums [43]. In addition, a very similar response has been reported in treated rose [21] and citrus [24] with the exogenous application of proline.

A higher content of phenolic compounds arises from the higher activity of the phenylpropanoid pathway, which depends on the higher PAL activity concurrent with the lower activity of PPO [61,62]. A higher content of phenols and flavonoids, along with higher ascorbic acid content as a non-enzymatic antioxidant system, participate in cellular ROS scavenging [59]. Preventing the activity of PPO by L-cysteine may be due to two reasons: (1) declining o-quinines generation and (2) the formation of stable-bound with copper that is located in the active sites of PPO enzyme $[10,13]$. Based on these results, the content of total phenols, flavonoids and the activity of the PAL enzyme increased; in contrast, the activity of PPO decreased in treated fruits with $15 \mathrm{mM}$ proline and $0.4 \%$ L-cysteine throughout the storage period. Increasing the activity of PAL/PPO and phenolic compounds' accumulation following the usage of L-cysteine in banana [63], carambola [48], litchi $[10,13]$, plums [43] and proline in rice [44] have also been reported.

In higher plants, the defense system is activated by increasing the process which osmoregulates the accumulation of various metabolites [64]. These osmolytes protect the structure of endogenous proline, the photosynthetic system and scavenge the ROS via cellular osmoregulation in response to abiotic stress [24,65]. A higher accumulation of proline has been detected under various environmental stresses, which represents the significant positive relationship with stress tolerance in higher plants [65]. So, increased accumulation of the content of endogenous proline in treated fruits with exogenous proline may be attributed to the osmoprotectant function of proline [24]. Results of the current study demonstrated that the application of exogenous proline and L-cysteine enhanced 
endogenous proline content during the cold storage life. Similar results have been reported in tomato [66], rice [22], Citrus [24] and barley [58].

\section{Conclusions}

In conclusion, the results of our research indicated that $15 \mathrm{mM}$ proline and $0.4 \%$ L-cysteine had higher efficiency in preserving the appearance and nutritional quality of flat peach fruit in cold storage conditions at $2{ }^{\circ} \mathrm{C}$ for 28 days. The mentioned treatments could prevent internal browning by controlling the activity of PPO and preserved the texture and flavor of treated fruits. Similarly, the application of proline and L-cysteine protected the structure of the cell membrane, which was demonstrated by lower levels of electrolyte leakage and MDA accumulation. In addition, the used treatments substantially increased the antioxidant capacity by enhancing the activity of SOD, CAT and APX enzymes and retained higher ascorbic acid, phenols and flavonoids along with markedly lower production of $\mathrm{H}_{2} \mathrm{O}_{2}$ in lower levels. Moreover, the activity of PAL/PPO ratio rose in treated peach fruits that led to a higher content of phenolic compounds and a lower manifestation of browning pigments. So, exogenous proline and L-cysteine could be considered safe and natural treatments to conserve eating quality and suppress the internal browning of flat peach fruits during postharvest storage.

Author Contributions: Conceptualization, G.G.; methodology, F.R.; Experiment design, G.G., F.R., J.M.L. and A.J.-M.; software, S.M.; validation, G.G. and F.R.; formal analysis, S.M., A.K. and M.G.; writing-original draft preparation, G.G. and S.M.; writing—review and editing, G.G., J.M.L. and A.J.-M.; supervision, G.G. and F.R.; project administration, F.R.; funding acquisition, F.R., A.J.-M. All authors have read and agreed to the published version of the manuscript.

Funding: This research received no external funding.

Institutional Review Board Statement: Not applicable.

Informed Consent Statement: Not applicable.

Data Availability Statement: The data presented in this study are available on request from the corresponding author.

Acknowledgments: Thanks to University of Maragheh and University of Zanjan for their kind supports during this project.

Conflicts of Interest: The authors declare no conflict of interest.

\section{References}

1. López-Gómez, A.; Navarro-Martínez, A.; Martínez-Hernández, G.B. Active Paper Sheets Including Nanoencapsulated Essential Oils: A Green Packaging Technique to Control Ethylene Production and Maintain Quality in Fresh Horticultural Products-A Case Study on Flat Peaches. Foods 2020, 9, 1904. [CrossRef]

2. Zhao, Y.; Song, C.; Brummell, D.A.; Qi, S.; Lin, Q.; Duan, Y. Jasmonic acid treatment alleviates chilling injury in peach fruit by promoting sugar and ethylene metabolism. Food Chem. 2021, 338, 128005. [CrossRef] [PubMed]

3. Lurie, S.; Crisosto, C.H. Chilling injury in peach and nectarine. Postharvest Biol. Technol. 2005, 37, 195-208. [CrossRef]

4. Redondo, D.; Venturini, M.E.; Oria, R.; Arias, E. Inhibitory effect of microwaved thinned nectarine extracts on polyphenol oxidase activity. Food Chem. 2016, 197, 603-610. [CrossRef]

5. Liu, H.; Jiang, W.; Cao, J.; Li, Y. Effect of chilling temperatures on physiological properties, phenolic metabolism and antioxidant level accompanying pulp browning of peach during cold storage. Sci. Hortic. 2019, 255, 175-182. [CrossRef]

6. Shaoying, Z.; Lishun, Z.; Xuyuan, D. Combined treatment of carbon monoxide and chitosan reduced peach fruit browning and softening during cold storage. Int. J. Food Sci. Nutr. 2015, 4, 477. [CrossRef]

7. Huan, C.; Han, S.; Jiang, L.; An, X.; Yu, M.; Xu, Y.; Yu, Z. Postharvest hot air and hot water treatments affect the antioxidant system in peach fruit during refrigerated storage. Postharvest Biol. Technol. 2017, 126, 1-14. [CrossRef]

8. Yang, C.; Chen, T.; Shen, B.; Sun, S.; Song, H.; Chen, D.; Xi, W. Citric acid treatment reduces decay and maintains the postharvest quality of peach (Prunus persica L.) fruit. Food Sci. Nutr. 2019, 7, 3635-3643. [CrossRef] [PubMed]

9. Pace, B.; Capotorto, I.; Ventura, M.; Cefola, M. Evaluation of L-cysteine as anti-browning agent in fresh-cut lettuce processing. J. Food Process. Preserv. 2015, 39, 985-993. [CrossRef]

10. Ali, S.; Khan, A.S.; Malik, A.U. Postharvest L-cysteine application delayed pericarp browning, suppressed lipid peroxidation and maintained antioxidative activities of litchi fruit. Postharvest Biol. Technol. 2016, 121, 135-142. [CrossRef] 
11. Li, T.; Wu, Q.; Zhou, Y.; Yun, Z.; Duan, X.; Jiang, Y. L-Cysteine hydrochloride delays senescence of harvested longan fruit in relation to modification of redox status. Postharvest Biol. Technol. 2018, 143, 35-42. [CrossRef]

12. Richard-Forget, F.C.; Goupy, P.M.; Nicolas, J.J. Cysteine as an inhibitor of enzymic browning. 2. Kinetic studies. J. Agric. Food Chem. 1992, 40, 2108-2113. [CrossRef]

13. Ali, S.; Khan, A.S.; Malik, A.U.; Nawaz, A.; Shahid, M. Postharvest application of antibrowning chemicals modulates oxidative stress and delays pericarp browning of controlled atmosphere stored litchi fruit. J. Food Biochem. 2019, 43, 12746. [CrossRef]

14. Gorny, J.R.; Hess-Pierce, B.; Cifuentes, R.A.; Kader, A.A. Quality changes in fresh-cut pear slices as affected by controlled atmospheres and chemical preservatives. Postharvest Biol. Technol. 2002, 24, 271-278. [CrossRef]

15. Rojas-Graü, M.A.; Sobrino-López, A.; Soledad Tapia, M.; Martín-Belloso, O. Browning inhibition in fresh-cut ‘Fuji'apple slices by natural antibrowning agents. J. Food Sci. 2006, 71, S59-S65. [CrossRef]

16. Ghidelli, C.; Mateos, M.; Rojas-Argudo, C.; Pérez-Gago, M.B. Extending the shelf life of fresh-cut eggplant with a soy proteincysteine based edible coating and modified atmosphere packaging. Postharvest Biol. Technol. 2014, 95, 81-87. [CrossRef]

17. Sohail, M.; Wills, R.B.H.; Bowyer, M.C.; Pristijono, P. Beneficial impact of exogenous arginine, cysteine and methionine on postharvest senescence of broccoli. Food Chem. 2021, 338, 128055. [CrossRef] [PubMed]

18. Zouari, M.; Hassena, A.B.; Trabelsi, L.; Rouina, B.B.; Decou, R.; Labrousse, P. Exogenous proline-mediated abiotic stress tolerance in plants: Possible mechanisms. In Osmoprotectant-Mediated Abiotic Stress Tolerance in Plants; Springer: Berlin/Heidelberg, Germany, 2019; pp. 99-121. [CrossRef]

19. Trovato, M.; Forlani, G.; Signorelli, S.; Funck, D. Proline metabolism and its functions in development and stress tolerance. In Osmoprotectant-Mediated Abiotic Stress Tolerance in Plants; Springer: Berlin/Heidelberg, Germany, 2019; pp. 41-72. [CrossRef]

20. Hossain, M.A.; Kumar, V.; Burritt, D.J.; Fujita, M.; Mäkelä, P.S. Osmoprotectant-Mediated Abiotic Stress Tolerance in Plants. In Proline Metabolism and Its Functions in Development and Stress Tolerance; Springer Nature: Cham, Switzerland, 2019 ; pp. 41-72. [CrossRef]

21. Kumar, N.; Pal, M.; Singh, A.; SaiRam, R.K.; Srivastava, G.C. Exogenous proline alleviates oxidative stress and increase vase life in rose (Rosa hybrida L.'Grand Gala'). Sci. Hortic. 2010, 127, 79-85. [CrossRef]

22. Hasanuzzaman, M.; Alam, M.; Rahman, A.; Hasanuzzaman, M.; Nahar, K.; Fujita, M. Exogenous proline and glycine betaine mediated upregulation of antioxidant defense and glyoxalase systems provides better protection against salt-induced oxidative stress in two rice (Oryza sativa L.) varieties. Biomed. Res. Int. 2014, 2014, 1-17. [CrossRef]

23. Kaushal, N.; Gupta, K.; Bhandhari, K.; Kumar, S.; Thakur, P.; Nayyar, H. Proline induces heat tolerance in chickpea (Cicer arietinum L.) plants by protecting vital enzymes of carbon and antioxidative metabolism. Physiol. Mol. Biol. Plants 2011, 17, 203-213. [CrossRef]

24. Mohammadrezakhani, S.; Hajilou, J.; Rezanejad, F.; Zaare-Nahandi, F. Assessment of exogenous application of proline on antioxidant compounds in three Citrus species under low temperature stress. J. Plant Interact. 2019, 14, 347-358. [CrossRef]

25. Fathi, H.; Dejampour, J.; Jahani, U.; Zarrinbal, M. Tree and fruit characterization of peach genotypes grown under Ardabil and East Azarbaijan environmental conditions in Iran. Crop. Breed. J. 2013, 3, 31-43. [CrossRef]

26. Wang, D.; Li, L.; Xu, Y.; Limwachiranon, J.; Li, D.; Ban, Z.; Luo, Z. Effect of exogenous nitro oxide on chilling tolerance, polyamine, proline, and $\gamma$-aminobutyric acid in bamboo shoots (Phyllostachys praecox f. prevernalis). J. Agric. Food Chem. 2017, 65, 5607-5613. [CrossRef] [PubMed]

27. Naser, F.; Rabiei, V.; Razavi, F.; Khademi, O. Effect of calcium lactate in combination with hot water treatment on the nutritional quality of persimmon fruit during cold storage. Sci. Hortic. 2018, 233, 114-123. [CrossRef]

28. Chen, J.Y.; He, L.H.; Jiang, Y.M.; Wang, Y.; Joyce, D.C.; Ji, Z.L.; Lu, W.J. Role of phenylalanine ammonia-lyase in heat pretreatmentinduced chilling tolerance in banana fruit. Physiol. Plant 2008, 132, 318-328. [CrossRef]

29. Hodges, D.M.; DeLong, J.M.; Forney, C.F.; Prange, R.K. Improving the thiobarbituric acid-reactive-substances assay for estimating lipid peroxidation in plant tissues containing anthocyanin and other interfering compounds. Planta 1992, 207, 604-611. [CrossRef]

30. Patterson, B.D.; MacRae, E.A.; Ferguson, I.B. Estimation of hydrogen peroxide in plant extracts using titanium (IV). Anal. Biochem. 1984, 139, 487-492. [CrossRef]

31. Dehghan, G.; Khoshkam, Z. Tin (II)-quercetin complex: Synthesis, spectral characterisation and antioxidant activity. Food Chem. 2012, 131, 422-426. [CrossRef]

32. Terada, M.; Watanabe, Y.; Kunitomo, M.; Hayashi, E. Differential rapid analysis of ascorbic acid and ascorbic acid 2-sulfate by dinitrophenylhydrazine method. Anal. Biochem. 1978, 84, 604-608. [CrossRef]

33. Zhang, Z.; Huber, D.J.; Rao, J. Antioxidant systems of ripening avocado (Persea americana Mill.) fruit following treatment at the preclimacteric stage with aqueous 1-methylcyclopropene. Postharvest Biol. Technol. 2013, 76, 58-64. [CrossRef]

34. Singleton, V.L.; Rossi, J.A. Colorimetry of total phenolics with phosphomolybdic-phosphotungstic acid reagents. Am. J. Enol. Vitic. 1965, 16, 144-158.

35. Zhishen, J.; Mengcheng, T.; Jianming, W. The determination of flavonoid contents in mulberry and their scavenging effects on superoxide radicals. Food Chem. 1999, 64, 555-559.

36. Sánchez, E.; López-Lefebre, L.R.; García, P.C.; Rivero, R.M.; Ruiz, J.M.; Romero, L. Proline metabolism in response to highest nitrogen dosages in green bean plants (Phaseolus vulgaris L. cv. Strike). J. Plant Physiol. 2001, 158, 593-598. [CrossRef]

37. Nguyen, T.B.T.; Ketsa, S.; van Doorn, W.G. Relationship between browning and the activities of polyphenol oxidase and phenylalanine ammonia lyase in banana peel during low temperature storage. Postharvest Biol. Technol. 2003, 30, 187-193. [CrossRef] 
38. Aghdam, M.S.; Bodbodak, S. Physiological and biochemical mechanisms regulating chilling tolerance in fruits and vegetables under postharvest salicylates and jasmonates treatments. Sci. Hortic. 2013, 156, 73-85. [CrossRef]

39. Zheng, X.; Tian, S.; Meng, X.; Li, B. Physiological and biochemical responses in peach fruit to oxalic acid treatment during storage at room temperature. Food Chem. 2007, 104, 156-162. [CrossRef]

40. Sodchit, C.; Kongbangkerd, T.; Phun, W.N. Prevention of enzymatic browning of postharvest longan fruit by N-acetyl-L-cysteine and 4-hexylresorcinol. Songklanakarin. J. Sci. Technol. 2008, 30, 31-35.

41. Cabezas-Serrano, A.B.; Amodio, M.L.; Colelli, G. Effect of solution pH of cysteine-based pre-treatments to prevent browning of fresh-cut artichokes. Postharvest Biol. Technol. 2013, 75, 17-23. [CrossRef]

42. Zhu, D.; Guo, R.; Li, W.; Song, J.; Cheng, F. Improved postharvest preservation effects of Pholiota nameko mushroom by sodium alginate-based edible composite coating. Food Bioproc. Technol. 2019, 12, 587-598. [CrossRef]

43. Banin Sogvar, O.; Razavi, F.; Rabiei, V.; Gohari, G. Postharvest application of L-cysteine to prevent enzymatic browning of "Stanley" plum fruit during cold storage. J. Food Process. Preserv. 2020, 44, 14788. [CrossRef]

44. Suekawa, M.; Fujikawa, Y.; Esaka, M. Exogenous proline has favorable effects on growth and browning suppression in rice but not in tobacco. Plant Physiol. Biochem. 2019, 142, 1-7. [CrossRef]

45. Öztürk, L.; Demir, Y. In vivo and in vitro protective role of proline. Plant Growth Regul. 2002, 38, 259-264. [CrossRef]

46. Khan, A.S.; Ullah, W.; Malik, A.U.; Ahmad, R.; Saleem, B.A.; Rajwana, I.A. Exogenous applications of boron and zinc influence leaf nutrient status, tree growth and fruit quality of Feutrell's early (Citrus reticulata Blanco). Pak. J. Agri. Sci. $2012,49,113-119$.

47. Barman, K.; Asrey, R.; Pal, R.K.; Kaur, C.; Jha, S.K. Influence of putrescine and carnauba wax on functional and sensory quality of pomegranate (Punica granatum L.) fruits during storage. J. Food Sci. Technol. 2014, 51, 111-117. [CrossRef]

48. Sharma, S.; Rao, T.R. Effect of honey and L-cysteine as antioxidants on the quality attributes of fresh-cut carambola (Averrhoa carambola L.) stored at two different temperatures. Int. J. Postharvest Technol. Innov. 2013, 24, 362-381. [CrossRef]

49. Wang, L.; Hou, Y.; Wang, Y.; Hu, S.; Zheng, Y.; Jin, P. Genome-wide identification of heat shock transcription factors and potential role in regulation of antioxidant response under hot water and glycine betaine treatments in cold stored peaches. J. Sci. Food Agric. 2021, 42, 11392. [CrossRef]

50. Y1ld1z, H.; Baysal, T. Effects of alternative current heating treatment on Aspergillus niger, pectin methylesterase and pectin content in tomato. J. Food Eng. 2006, 75, 327-332. [CrossRef]

51. Plotto, A.; Narciso, J.A.; Rattanapanone, N.; Baldwin, E.A. Surface treatments and coatings to maintain fresh-cut mango quality in storage. J. Sci. Food Agric. 2010, 90, 2333-2341. [CrossRef] [PubMed]

52. Alandes, L.; Quiles, A.; Pérez-Munuera, I.; Hernando, I. Improving the quality of fresh-cut apples, pears, and melons using natural additives. J. Food Sci. 2009, 74, S90-S96. [CrossRef] [PubMed]

53. Jambunathan, N. Determination and detection of reactive oxygen species (ROS), lipid peroxidation, and electrolyte leakage in plants. In Plant Stress Tolerance; Humana Press: Totowa, NJ, USA, 2010; pp. 291-297. [CrossRef]

54. Catalá, A. An overview of lipid peroxidation with emphasis in outer segments of photoreceptors and the chemiluminescence assay. Int. J. Biochem. Cell Biol. 2006, 38, 1482-1495. [CrossRef] [PubMed]

55. Molaei, S.; Rabiei, V.; Soleimani, A.; Razavi, F. Exogenous application of glycine betaine increases the chilling tolerance of pomegranate fruits cv. Malase Saveh during cold storage. J. Food Process. Preserv. 2021, 45, 15315. [CrossRef]

56. Nasibi, F.; Farahmand, H.; Kamyab, A.; Alipour, S. Effects of arginine, cysteine and 5-sulfosalicylic acid on of vase life of tuberose cut flowers. Agric. Commun. 2014, 2, 35-41.

57. Li, Z.G.; Jin, J.Z. Hydrogen sulfide partly mediates abscisic acid-induced heat tolerance in tobacco (Nicotiana tabacum L.) suspension cultured cells. Plant Cell Tissue Organ. Cult. (PCTOC) 2016, 125, 207-214. [CrossRef]

58. Abdelaal, K.A.; Attia, K.A.; Alamery, S.F.; El-Afry, M.M.; Ghazy, A.I.; Tantawy, D.S.; Al-Doss, A.A.; El-Shawy, E.S.E.; Abu-Elsaoud, A.M.; Hafez, Y.M. Exogenous application of proline and salicylic acid can mitigate the injurious impacts of drought stress on barley plants associated with physiological and histological characters. Sustainability 2020, 12, 1736. [CrossRef]

59. Aghdam, M.S.; Dokhanieh, A.Y.; Hassanpour, H.; Fard, J.R. Enhancement of antioxidant capacity of cornelian cherry (Cornus mas) fruit by postharvest calcium treatment. Sci. Hortic. 2013, 161, 160-164. [CrossRef]

60. Dokhanieh, A.Y.; Aghdam, M.S.; Fard, J.R.; Hassanpour, H. Postharvest salicylic acid treatment enhances antioxidant potential of cornelian cherry fruit. Sci. Hortic. 2013, 154, 31-36. [CrossRef]

61. Aghdam, M.S.; Naderi, R.; Sarcheshmeh, M.A.A.; Babalar, M. Amelioration of postharvest chilling injury in anthurium cut flowers by $\gamma$-aminobutyric acid (GABA) treatments. Postharvest Biol. Technol. 2015, 110, 70-76. [CrossRef]

62. Molaei, S.; Soleimani, A.; Rabiei, V.; Razavi, F. Impact of chitosan in combination with potassium sorbate treatment on chilling injury and quality attributes of pomegranate fruit during cold storage. J. Food Biochem. 2021, 45, 13633. [CrossRef] [PubMed]

63. Bico, S.L.S.; de Jesus Raposo, M.F.; De Morais, R.M.S.C.; De Morais, A.M.M.B. Chemical dips and edible coatings to retard softening and browning of fresh-cut banana. Int. J. Postharvest Technol. Innov. 2010, 2, 13-24. [CrossRef]

64. Szabados, L.; Savouré, A. Proline: A multifunctional amino acid. Trends Plant Sci. 2010, 15, 89-97. [CrossRef] [PubMed]

65. Ashraf, M.F.M.R.; Foolad, M.R. Roles of glycine betaine and proline in improving plant abiotic stress resistance. Environ. Exp. Botany 2007, 59, 206-216. [CrossRef]

66. Heuer, B. Influence of exogenous application of proline and glycinebetaine on growth of salt-stressed tomato plants. Plant Sci. 2003, 165, 693-699. [CrossRef] 